\begin{tabular}{ccc}
\hline & International Journal of Advanced Geosciences, 8(2)(2020) 231-236 \\
SPC & Website: www.sciencepubco.com/index.php/IJAG \\
Research paper & Resciences \\
\hline
\end{tabular}

\title{
The geological setting of arsenic enrichment in groundwater of the shallow aquifers of the Tista Floodplain, Rangpur, Bangladesh
}

\author{
Sudip Saha ${ }^{1}$ *, A.H.M. Selim Reza ${ }^{1}$, Mrinal Kanti Roy ${ }^{1}$ \\ ${ }^{1}$ Department of Geology and Mining, University of Rajshahi, Rajshahi-6205, Bangladesh \\ *Corresponding author E-mail: sudips_geologist@yahoo.com
}

\begin{abstract}
Arsenic is present in water samples within the studied active floodplain areas of the Tista river, Rangpur Division, Bangladesh. All the water samples contain less arsenic than the WHO prescribed limit of $10 \mu \mathrm{g} / \mathrm{L} .93 .33 \%$ groundwater samples have higher Mn content than the permissible limit of $0.01 \mathrm{mg} / \mathrm{L}$ of WHO. The heavy metal concentrations of water can be expressed as Fe $>\mathrm{Mn}>\mathrm{Zn}>\mathrm{As}$ on the basis of their mean content. The heavy metals are negatively correlated with the well depth which is indicative of the influence of the anthropogenic activities on the concentrations of heavy metals. The arsenic concentration in water samples is higher in the central part of the study area. The coarser grain size, dominance of physical weathering, elevated topography and the effective flushing of groundwater resulted low concentration of arsenic in the groundwater. The EDS study reveals that arsenic occurs as coating materials of the silicate minerals. The river waters also have arsenic content lower than WHOs permissible limit. The factor analysis reveals that the iron and arsenic is released by the chemical weathering of arsenic bearing minerals like pyrite and arsenopyrite. The Fe and $\mathrm{Mn}$ derived in the groundwater by the chemical weathering of iron and manganese bearing minerals such as iron rich clay, silicate minerals and iron sulfides.
\end{abstract}

Keywords: Arsenic; Groundwater; Topography; Grain Size; Factor Analysis and Silicate Minerals.

\section{Introduction}

Higher concentration of arsenic (As) in groundwater is a prime environmental problem in the aquifers of mega-deltas and low-lying floodplains of South-east and South Asia (Fendorf et al. 2010). Studies reveal that about three million tubewells, installed at shallow depths (10 to 50m) in Bangladesh, discharge groundwater with above $50 \mu \mathrm{g} / \mathrm{L}$ (Ahmed et al. 2004: Zahid et al. 2008). Forty-six to fifty-seven million Bangladeshi people are exposed to drinking water containing arsenic $10 \mu \mathrm{g} / \mathrm{L}$ (DPHE-BGS 2001). Arsenic is present in groundwater at Siliguri-Jalpaiguri area, West Bengal, India and exactly $32 \%$ of the samples contain arsenic above the WHO prescribed limit of $10 \mu \mathrm{g} / \mathrm{L}$ (Bhattacharyya and Mukherjee 2008). In this area, the Tista River descending from the Himalayas and meets the alluvial plain.

The Tista and Brahmaputra River floodplains in Bangladesh have the lowest arsenic concentrations in shallow groundwaters whereas the Meghna River floodplains are reported to have high arsenic concentrations in tubewells (DPHE-BGS 2001: Ravenscroft 2001). Twentyfive percent of 524 wells beneath the Tista and Brahmaputra floodplains exceeding arsenic concentrations $50 \mu \mathrm{g} / \mathrm{L}$ (Ravenscroft et al. 2005). On the basis of the arsenic content in groundwater, the Tista floodplain aquifer can be categorized into two zones- the first zone which is fairly arsenic safe in the upper course in Nilphamari, Lalmonihat and Rangpur, and the next zone where $20 \%$ to $40 \%$ wells contain higher arsenic in groundwater. In particular, large part of the Tista floodplains are underlain by medium and coarse sand (Ravenscroft et al. 2005). The aim of the present research work is to determine the geochemical condition of low arsenic groundwater that was long awaited. 


\section{Hydrogeology}

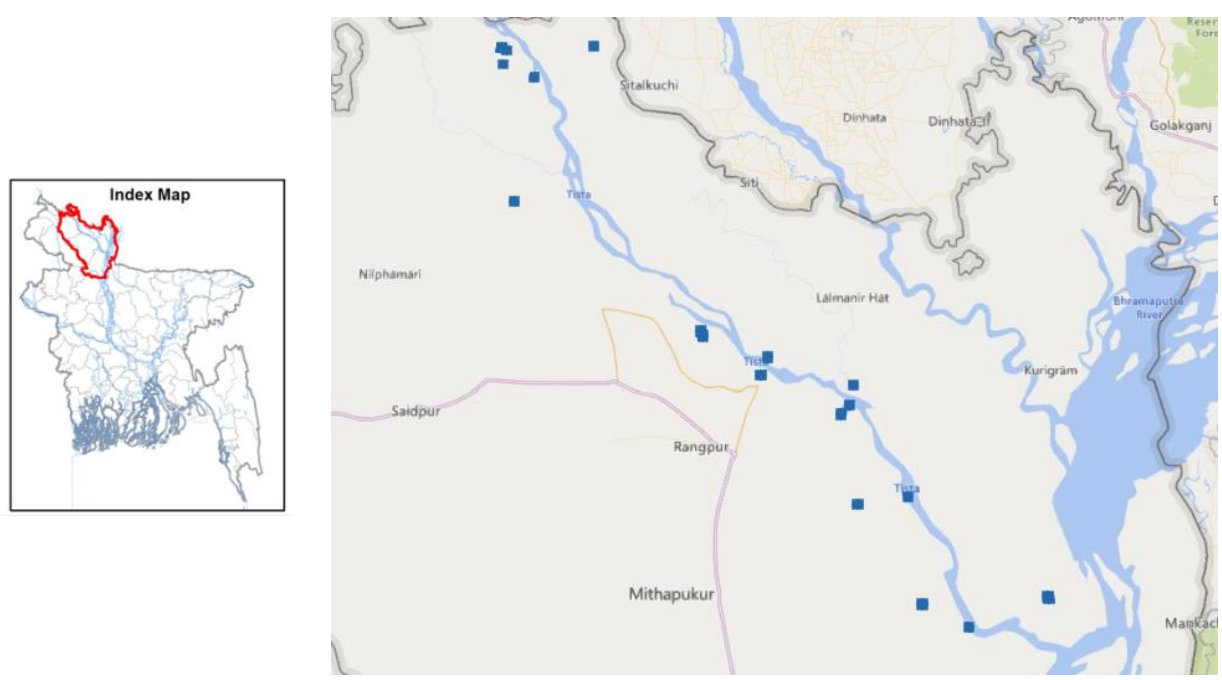

Fig. 1: Map of the Study Area, Rangpur, Bangladesh.

The Tista floodplain is characterized by big sub-region which stretches between the Old Himalayan Piedmont Plain in the west and right bank of the N-S flowing Brahmaputra in the east (Islam et al. 2016). The total catchment area of the Tista river is $12159 \mathrm{sq} . \mathrm{km}$. According to Environmental Information System (ENVIS) centre Sikkim, total catchment area $10155 \mathrm{sq} . \mathrm{km}$ in India, and 2004 sq. km in Bangladesh. In Bangladesh the Tista river flows through Nilphamari, Lalmonirhat, Rangpur, Kurigram and Gaibandha districts of Rangpur division (Figure 1). The main tributaries of the Tista river are BuriTista and Trimohini in Bangladesh. The Tista river flows to the Brahmaputra River at Fulchary near Chilmari (Wasleker 2013). Estimates have suggested that the Tista River has a mean annual flow of approximately 60 BCM (Wasleker 2013). A significant amount of this water flows during the monsoon season i.e. between June and September. The significance of the flow and seasonal variation of this river is understood during the lean period (October to April/May) as the average flow is about $500 \mathrm{MCM}$ per month. The mean annual rainfall in Northwest Bangladesh is $1,971 \mathrm{~mm}$ (Walseker 2013). In the study area, the mean daily maximum temperature varies from $20^{\circ} \mathrm{C}$ in January to $29^{\circ} \mathrm{C}$ in April and June. The mean daily minimum temperatures range from $9^{\circ} \mathrm{C}$ in January and February to $19^{\circ} \mathrm{C}$ in July, August and October. There is a strong correlation between surface and groundwater resources in Tista floodplain (Walseker 2013). The Tista is an influent river that have a net flow from the river to the groundwater aquifer (CSIRO, WARPO, BWDB, IMW, BIDS, CEGIS, 2014).

The elevation in northwestern parts of Bangladesh (Tista Alluvial Fan) is higher than rest of the geomorphic units except the Hills of the Tertiary age (Shamsudduha et al. 2009). Most of the land shallowly flooded during monsoons.

Most of the aquifers occur at $50 \mathrm{~cm}$ to $130 \mathrm{~m}$ depth (Haque and Tasnuva, 2016). The aquifer is mainly unconfined in nature. Tista floodplain aquifers are composed of sand and gravel (Majumder et al. 2011, 2013). Rainwater is the principal source of groundwater recharge in the study area. Flood water that overflows the river and stream banks also infiltrates into the groundwater. Analysis of groundwater level and river-stage hydrographs (Shamsudduha et al. 2011) reveals that all river channels rise above groundwater levels in adjacent aquifers during the monsoon season (May-September); indirect recharge is restricted to lateral river-bank infiltration during the early monsoon time (AprilJune). The groundwater flows generally from north to south of the investigated area. The transmissivity values of the aquifer vary from $1000 \mathrm{~m}^{2} /$ day to $7000 \mathrm{~m}^{2} /$ day (Hussain and Abdullah 2001).

The main sources of surface water of the study area are Tista river, beels, lakes and ponds. During the summer months the flow of the Tista river is lowest and in most of the parts of the river bed dries up. The inhabitants depend mainly on groundwater for drinking and irrigation purposes. Groundwater development by tubewells requires a complete understanding of the aquifer properties, quality and quantity of the groundwater.

\section{Materials and methods}

From the tubewells water samples were collected in order to study physico-chemical characters of the studied water. The groundwater samples were collected from both shallow and deep tubewells. The $\mathrm{pH}$, electrical conductance (EC) and temperature of the groundwater were measured and recorded in situ. Sampling was carried out using pre-cleaned polythene bottles, after pumping continuously 10-15 minutes until the temperature, electrical conductivity (EC) and $\mathrm{pH}$ reading had stabilized (in case of groundwater). Collected samples were preserved at $4{ }^{\circ} \mathrm{C}$ and taken into the laboratory for chemical analyses. Heavy metal concentrations were determined by Atomic Absorption Spectrometer, model Shimadzu AA 7000. Thirty-five to forty sand particles were randomly selected for SEM analysis. The elemental analyses were also performed using EDS attached with scanning electron microscope.

\section{Results and Discussion}

The $\mathrm{pH}$ values of natural water vary from 6.20 to 8.50 whereas the mean value is 6.89 . The $\mathrm{pH}$ values of the river water are higher than the $\mathrm{pH}$ values of groundwater samples. The median $\mathrm{pH}$ value of the river water samples is 8.2 that indicate the alkaline nature of the river water. The mean $\mathrm{pH}$ value of the groundwater 6.55 which is indicative of acidic nature of the groundwater samples of the investigated area (Saha et al. 2019). 
Table 1: Statistical Summary of Heavy Metal Concentrations of Groundwater and River water, Rangpur

\begin{tabular}{|c|c|c|c|c|c|c|}
\hline & Depth, m & $\mathrm{pH}$ & As $\mu \mathrm{g} / \mathrm{L}$ & $\mathrm{Mn} \mathrm{mg} / \mathrm{L}$ & $\mathrm{Zn} \mathrm{mg/L}$ & $\mathrm{Fe} \mathrm{mg} / \mathrm{L}$ \\
\hline Mean & 15.72 & 6.89 & 1.25 & 0.59 & 0.01 & 1.26 \\
\hline Median & 12.20 & 6.60 & 1.25 & 0.54 & 0.00 & 0.75 \\
\hline $\mathrm{SD}$ & 17.52 & 0.73 & 0.35 & 0.59 & 0.05 & 1.58 \\
\hline Variance & 306.84 & 0.54 & 0.13 & 0.34 & 0.00 & 2.49 \\
\hline Skewness & 2.50 & 1.24 & 0.05 & 0.77 & 4.26 & 2.00 \\
\hline Kurtosis & 7.88 & 0.17 & -0.97 & -0.30 & 18.36 & 3.57 \\
\hline Max & 76.25 & 8.50 & 1.87 & 1.91 & 0.21 & 5.74 \\
\hline Min & 0.00 & 6.20 & 0.67 & 0.00 & 0.00 & 0.07 \\
\hline Range & 76.25 & 2.30 & 1.20 & 1.91 & 0.21 & 5.66 \\
\hline Sum & 298.64 & 130.90 & 23.77 & 11.23 & 0.26 & 23.85 \\
\hline
\end{tabular}
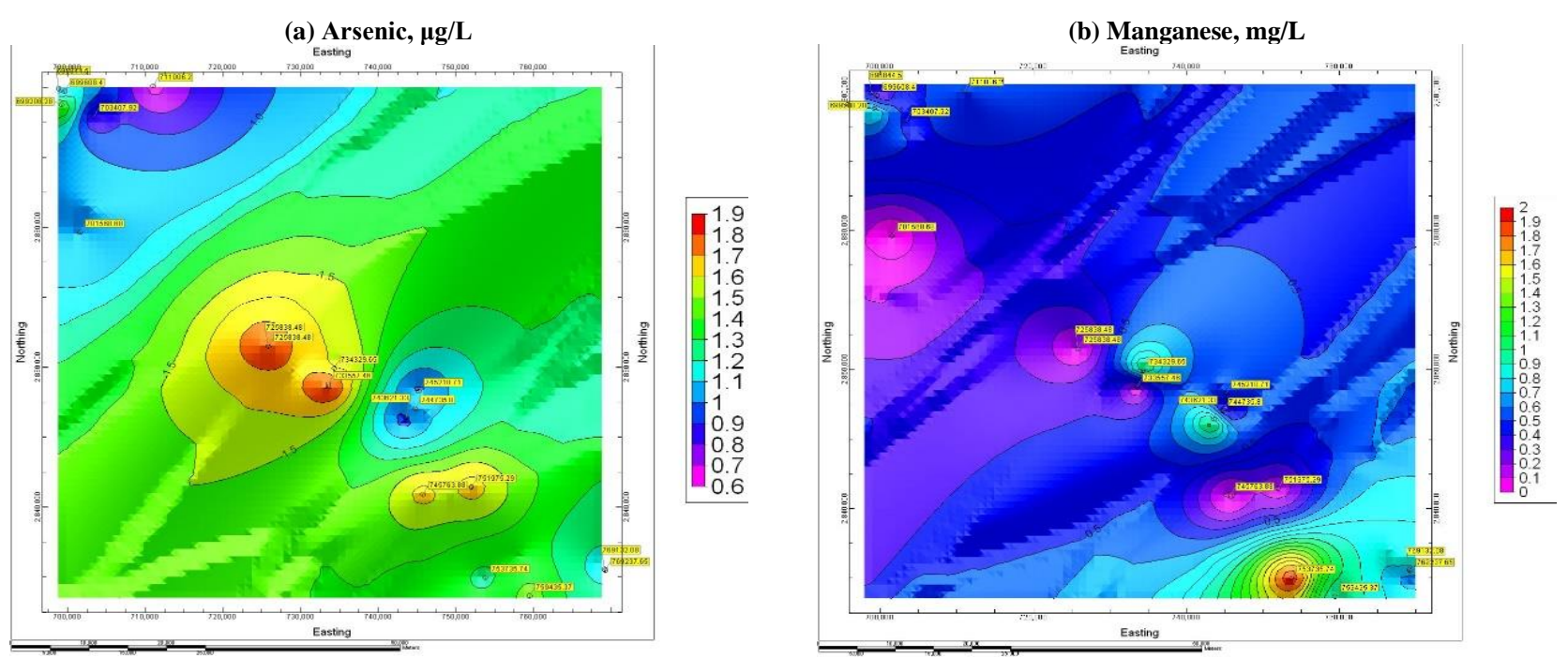

Fig. 2: Spatial Distribution of a) Arsenic and b) Manganese Concentrations of Water of the Study Area.

The average arsenic concentration of the water samples of the study area is $1.25 \mu \mathrm{g} / \mathrm{L}$. The maximum and minimum values of arsenic content of the groundwater are $1.87 \mu \mathrm{g} / \mathrm{L}$ and $0.67 \mu \mathrm{g} / \mathrm{L}$ respectively. The median value for arsenic concentrations of the river water is 1.37 $\mu \mathrm{g} / \mathrm{L}$. The findings of the present research work reveals that the arsenic content of the water samples are below the permissible As concentration value of $10 \mu \mathrm{g} / \mathrm{L}$ of WHO, 2008. Figure 2a shows the spatial distribution of arsenic concentrations of natural water samples of the investigated area and it is revealed that the As concentration is highest in the central part of the study area.

The present study reveals that the $\mathrm{Mn}$ concentrations of groundwater samples range from 0 to $1.91 \mathrm{mg} / \mathrm{L}$ with the mean value of $0.74 \mathrm{mg} / \mathrm{L}$. Eighty percent of the groundwater samples exceed the permissible limit of Mn, $0.10 \mathrm{mg} / \mathrm{L}$ for Bangladesh Drinking Water Standard (BD DWS) and 93.33\% groundwater samples have higher Mn content than the permissible limit of $0.01 \mathrm{mg} / \mathrm{L}$ of WHO, 2011. Figure $2 \mathrm{~b}$ shows the lateral distribution of $\mathrm{Mn}$ and it is clearly shown that the concentration of $\mathrm{Mn}$ is higher in the south eastern part of the study area. The maximum Mn content of groundwater is reported from Sundarganj Upazila of Gaibandha district. The manganese concentrations of river water samples are lower than the Mn concentrations of groundwater. The average $\mathrm{Mn}$ content value of river water is $0.04 \mathrm{mg} / \mathrm{L}$.

The $\mathrm{Zn}$ content of all river water samples are zero. In groundwater samples, the zinc concentrations vary from 0 to $0.21 \mathrm{mg} / \mathrm{L}$, with the mean value of $0.02 \mathrm{mg} / \mathrm{L}$. The highest amount of zinc is reported from the groundwater of Pirgacha Upazila Rangpur district. The concentration of zinc increases to the downstream direction. The average concentration of $\mathrm{Zn}$ in groundwater of the study area is low.

The concentrations of iron in groundwater samples range from $0.071 \mathrm{mg} / \mathrm{L}$ to $4.790 \mathrm{mg} / \mathrm{L}$. The mean iron concentration of groundwater is $1.16 \mathrm{mg} / \mathrm{L}$. The iron concentrations of $1-3 \mathrm{mg} / \mathrm{L}$ can be acceptable for people drinking anaerobic well-water (WHO 2003). The present study reveals that only one groundwater sample exceeds the maximum acceptable limit of WHO, 2003. The maximum iron concentration is reported from the groundwater sample of Kaunia, Rangpur. The mean iron concentrations of river water are $1.60 \mathrm{mg} / \mathrm{L}$, with the maximum value of $5.74 \mathrm{mg} / \mathrm{L}$ in Gangachara, Rangpur.

Table 2: Pearson Correlation Coefficient Matrix of Heavy Metals of Groundwater $(\mathrm{n}=15)$

\begin{tabular}{|c|c|c|c|c|c|c|}
\hline & Depth & $\mathrm{pH}$ & As & $\mathrm{Mn}$ & $\mathrm{Zn}$ & $\mathrm{Fe}$ \\
\hline Depth & 1.000 & & & & & \\
\hline $\mathrm{pH}$ & 0.019 & 1.000 & & & & \\
\hline As & -0.307 & 0.370 & 1.000 & & & \\
\hline $\mathrm{Mn}$ & -0.023 & -0.151 & -0.173 & 1.000 & & \\
\hline $\mathrm{Zn}$ & -0.153 & $0.777 * *$ & 0.335 & -0.254 & 1.000 & \\
\hline $\mathrm{Fe}$ & -0.234 & -0.129 & 0.207 & -0.201 & -0.121 & 1.000 \\
\hline
\end{tabular}

* Correlation is significant at the 0.05 level (2-tailed).

** Correlation is significant at the 0.01 level (2-tailed).

The well depth shows insignificant negative correlations with As $(R=-0.307), \mathrm{Mn}(\mathrm{R}=-0.023), \mathrm{Zn}(\mathrm{R}=-0.153)$ and $\mathrm{Fe}(\mathrm{R}=-0.234)$ content of groundwater (Table 2). The negative correlations between well depth and heavy metal concentrations imply that anthropogenic activities might have influence on the concentrations of these metals in the study area.

The $\mathrm{pH}$ shows insignificant positive correlation with arsenic $\left(\mathrm{R}^{2}=0.1371\right)$ and strongly significant positive correlations with zinc $\left(\mathrm{R}^{2}=0.6039\right)$ content of groundwater samples of the shallow aquifers of the Tista River Basin (Figure 3 and 4). The positive correlations between $\mathrm{pH}$ and arsenic are noticed from the groundwater samples of United States of America (Ayotte et al. 2003) and in Argentina (Smedley et al. 2002) and it reveals that the arsenic mobility within the groundwater is controlled by sorption/desorption processes, indicating the possibility of geologically related mineral interferences with aquifer or surface waters (Katsoyiannis and Katsoyiannis 2006). 


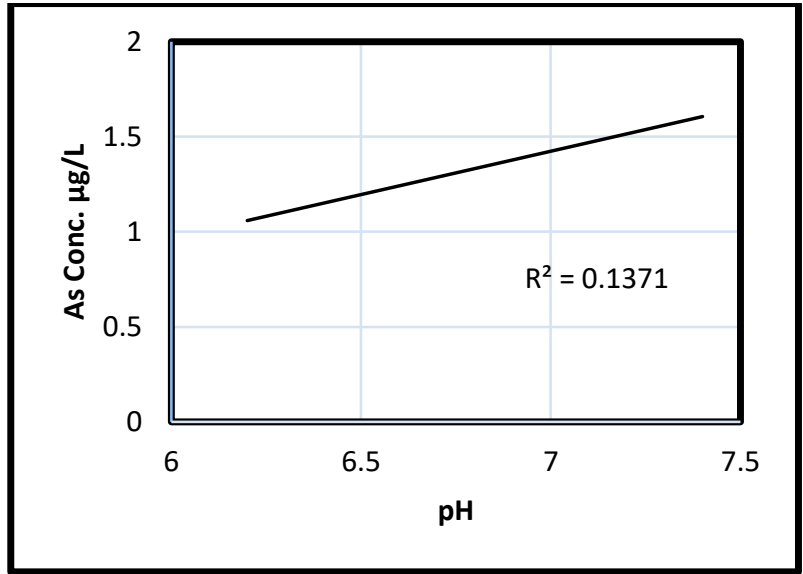

Fig. 3: Correlation of pH vs As

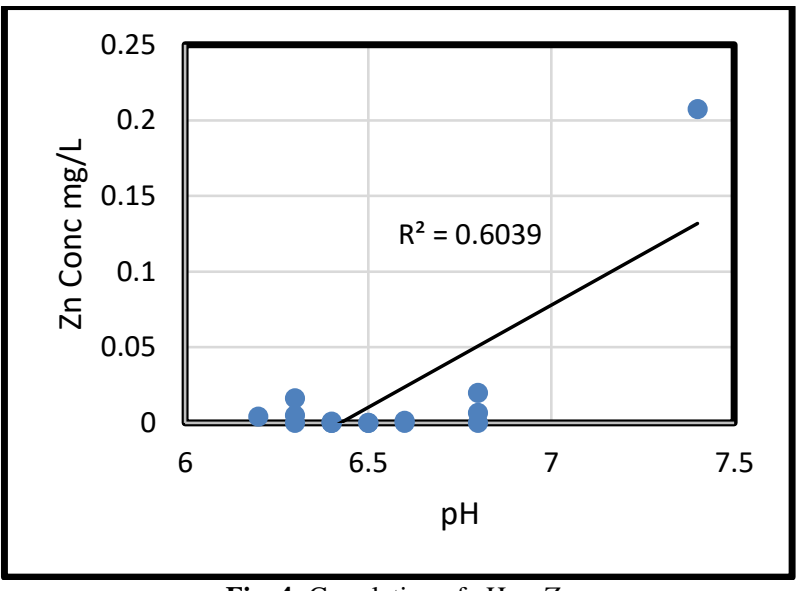

Fig. 4: Correlation of $\mathrm{pH}$ vs $\mathrm{Zn}$

The dissolution of different arsenic bearing minerals like realgar (AsS), orpiment ( $\mathrm{As}_{2} \mathrm{~S} 3$ ), arsenopyrite ( $\left.\mathrm{FeAsS}\right)$, enargite $\left(\mathrm{Cu}_{3} \mathrm{AsS}_{4}\right)$ release arsenic into the groundwater (UN Report 2001: Moni et al. 2019). The XRD analyses of the sediments of the upper part of the aquifers reveal that they contain As-bearing mineral lavendulan $[\mathrm{Na}, \mathrm{Ca}, \mathrm{Cu} 5$ (AsO4)4 Cl. 5H2O] in trace amounts only in two locations (Saha et al. 2018, 2020).

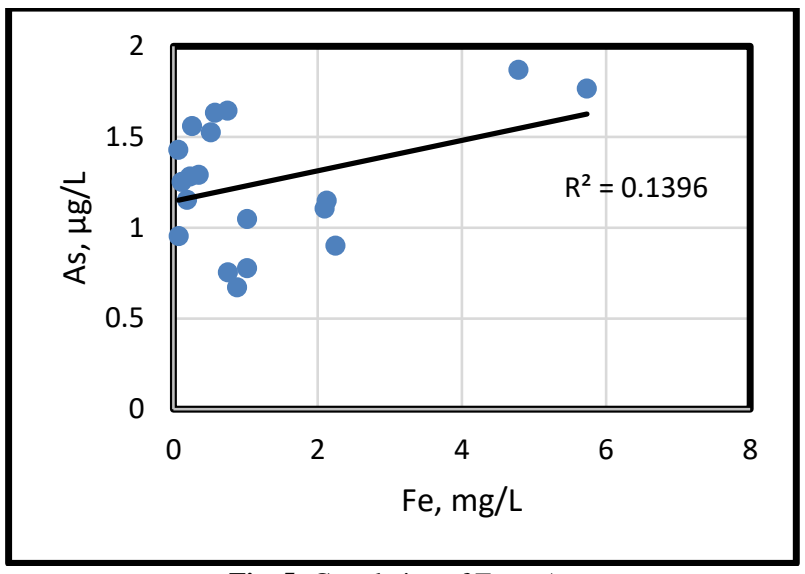

Fig. 5: Correlation of Fe vs As.

The poor positive relationship between As and Fe is observed in the investigated area (Figure 5). This poor correlation reveals that the pyrite/sulfide oxidation may release arsenic to the groundwater in small quantities (Reza et al. 2010). The arsenic concentrations in the sediments of Bengal Basin range from 0.4 to $40 \mathrm{mg} / \mathrm{Kg}$ (DPHE-BGS, 2001: Reza et al. 2010c). The geochemical study of the Tista River sediments show that the average arsenic concentration is $3.52 \mathrm{mg} / \mathrm{Kg}$. The dominance of the coarser particles in the study area is one of the factor that result low arsenic concentrations. The illite crystallization index shows that physical weathering is the dominant in Rangpur (Saha et al, 2020). The study reveals that $93.33 \%$ groundwater samples have higher $\mathrm{Mn}$ content than the permissible limit of $0.01 \mathrm{mg} / \mathrm{L}$ of WHO. The insignificant negative correlation between $\mathrm{Mn}$ and As indicates that the source of arsenic and manganese in groundwater are different (Table 2). The EDS study shows the arsenic occurs as coating materials in platy micaceous minerals. The natural sources of iron and manganese include their derivation by the weathering of iron and manganese bearing minerals such as iron rich clay, silicate minerals and iron sulfides (Luzati et al. 2016). The shallow groundwater is free of excessive arsenic in places where the elevation is high especially in recharge areas and results remarkably higher hydraulic gradients that drive more effective groundwater flushing (Stute et al. 2007: Aziz et al. 2008: Weinman et al. 2008: Hoque et al. 2017). The present study shows that the manganese concentration of river is lower than the groundwater. The studied aquifers are in the active floodplains of the Tista River and it is an influent river, so the input of the river water into the aquifer can also lower the manganese concentration of the groundwater.

\section{Factor analysis}

Table 3: Total Variance Explained

\begin{tabular}{lllllll}
\hline \multirow{2}{*}{ Component } & \multicolumn{2}{c}{ Initial Eigenvalues } & \multicolumn{5}{c}{ Extraction Sums of Squared Loadings } \\
& Total & \% of Variance & Cumulative \% & Total & \% of Variance & Cumulative \% \\
\hline 1 & 2.207 & 36.789 & 36.789 & 2.207 & 36.789 & 36.789 \\
2 & 1.132 & 18.868 & 55.657 & 1.132 & 18.868 & 55.657 \\
3 & 1.008 & 16.792 & 72.449 & 1.008 & 16.792 & 72.449 \\
4 & .772 & 12.864 & 85.313 & & & \\
5 & .477 & 7.946 & 93.258 & & & \\
6 & .404 & 6.742 & 100.000 & & & \\
\hline
\end{tabular}

Extraction Method: Principal Component Analysis. 


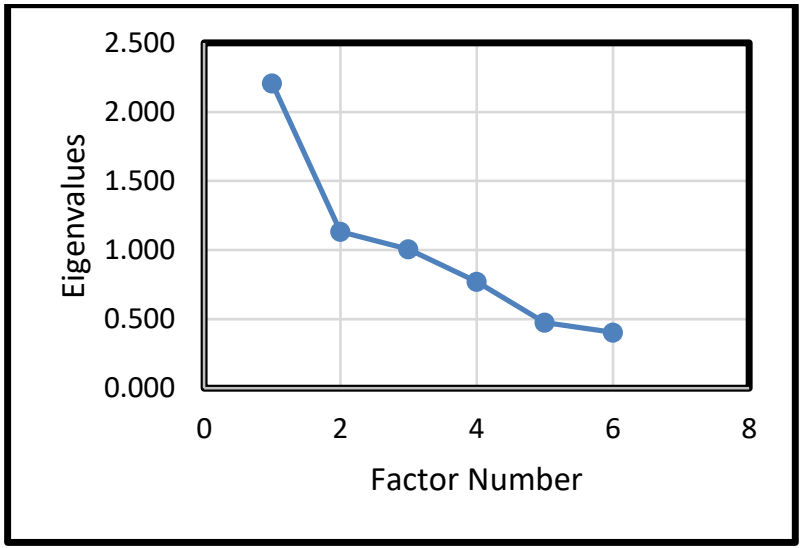

Fig. 6: Scree Plot for Heavy Minerals of the Study Area.

Table 4: Varimax Rotated Factors for First Three Components

\begin{tabular}{llll}
\hline & Component & Factor-2 & Factor-3 \\
\hline Depth & Factor-1 & -.127 & .165 \\
$\mathrm{pH}$ & -.665 & -.241 & -.386 \\
$\mathrm{As}$ & .750 & .175 & .503 \\
$\mathrm{Mn}$ & .697 & .224 & .374 \\
$\mathrm{Zn}$ & -.653 & -.639 & .628 \\
$\mathrm{Fe}$ & .323 & .755 & .208 \\
\hline
\end{tabular}

As describes in Table 3, the first three factors represent the ratios of $36.789 \%, 18.868 \%$ and $16.7922 \%$ respectively, and they comprise $72.449 \%$ of the total variability of the original data. The first factor (Factor-1) is characterized by the dominance of $\mathrm{pH}$ and arsenic content of the natural water and indication chemical weathering of the arsenic bearing minerals like pyrite and arsenopyrite. The second factor (Factor-2) provides data about the release of iron in the groundwater. The third factor (Factor-3) is highly affected by the contamination of zinc of the water.

\section{Conclusion}

Arsenic is present in water samples within the studied floodplain areas of the Tista river. All the water samples contain less arsenic than the WHO prescribed limit of $10 \mu \mathrm{g} / \mathrm{L}$. The low arsenic concentration of the aquifers might have resulted as (1) the sediments have lower arsenic concentrations in comparison with arsenic affected areas, (2) the EDS study reveals that arsenic occurs as coating materials of silicate (3) prevalence of the coarser sediments in the investigated aquifers, (4) the dominance of physical weathering and (5) elevated topography and remarkably higher hydraulic gradients that result more effective groundwater flushing. The factor analysis reveals that the arsenic is released in small quantities by the chemical weathering of arsenic bearing minerals. The river waters also have arsenic content lower than WHOs permissible limit. The wells are safe considering the arsenic concentrations of groundwater whereas $93.33 \%$ of the groundwater samples have higher Mn content than the permissible limit of $0.01 \mathrm{mg} / \mathrm{L}$ of WHO. The future research works can be taken on the safe removal of manganese from the groundwater.

\section{Acknowledgement}

The authors are grateful to Professor Dr Hasan Ahmad, Department of Chemistry, University of Rajshahi for providing kind permission to analyze the water samples in the Central Science Laboratory, University of Rajshahi. The authors convey due thanks to Professor Dr. Golam Shabbir Sattar, Ex-Chairman and Professor Dr. Khondaker Emamul Haque, Ex-Chairman Department of Geology and Mining, University of Rajshahi, Bangladesh for arranging the research work. Special thanks to Department of Glass and Ceramic Engineering, BUET for providing permission to analyze sediments in the laboratory. Finally, the authors are pleased to thank Mr. Sreekanta Saha for his kind help during the field work.

Funding: No funding

Conflict of interest: No conflict of interest.

\section{References}

[1] Ahmed KM, Bhattacharya P, Hassan MA, Akhter SH, Alam SMM, Bhuyian MAH, Imam MB, Khan, AA, Sracek O (2004) Arsenic Enrichment in Groundwater of the Alluvial aquifers in Bangladesh: An Overview. Applied Geochemistry 19: 181-200. https://doi.org/10.1016/j.apgeochem.2003.09.006.

[2] Ayotte JD, Montgomery DL, Flanagan SM, Robinson KW (2003) Arsenic in Groundwater in eastern New England: Occurrence, controls and human health implications. Environ. Sci. Technology 37: 2075-2083. https://doi.org/10.1021/es026211g.

[3] Aziz Z, van Geen A, Stute M, Versteeg R, Horneman A, Zheng Y, Goodbred S, Steckler M, Weinman B, Gavrieli I, Hoque MA, Shamsudduha M, Ahmed KM, (2008) Impact of local recharge on arsenic concentrations in shallow aquifers inferred from the electromagnetic conductivity of soils in Araihazar, Bangladesh. Water Resour. Res. 44: W07426. https://doi.org/10.1029/2007WR006000.

[4] Bhattacharyya D, Mukherjee PK (2008) Contamination of shallow aquifers by arsenic in upper reaches of Tista river at Siliguri-Jalpaiguri area of West Bengal, India. Environmental Geology 57(7): 1687-1692. https://doi.org/10.1007/s00254-008-1450-6.

[5] CSIRO, WARPO, BWDB, IMW, BIDS, CEGIS (2014) Bangladesh Integrated Water Resources Assessment: final report. CSIRO, Australia. 
[6] DPHE-BGS (2001) Arsenic Contamination of Groundwater in Bangladesh. British Geological Survey and Department of Public Health Engineering, Govt. of Bangladesh: rapid investigation phase, Final Report.

[7] Fendorf S, Michael HA, van Geen, A (2010) Spatial and Temporal Variations of Groundwater Arsenic in South and Southeast Asia. Science 328(5982): 1123-1127. https://doi.org/10.1126/science.1172974.

[8] Hoque MA, Burgess WG and Ahmed KM (2017) Integration of aquifer geology, groundwater flow and arsenic distribution in deltaic aquifers - a unifying concept. Hydrological Processes. https://doi.org/10.1002/hyp.11181.

[9] Hussain, M.M., Abdullah, SKM (2001) Geological Setting of the Areas of Arsenic Aquifers, Ground Water Task Force, Interim Report No.1, Local Government Division, Minitry of Local Government, Rural Development \& Cooperatives, Bangladesh, pp. A 1-A 45. http://fineprint.com.

[10] Islam K, Rahman MS, Ali MH, Hossain AFMA, Alam MJ, Zahid A (2016) Evaluation of the Aquifer System and Groundwater Quality of the NorthWestern districts of Bangladesh for Development Potential. BRAC University Journal XI (2): 85-100.

[11] Katsoyiannis IA, Katsoyiannis AA (2006) Arsenic and Other Metal contamination of Groundwaters in Industrial Area of Thessaloniki, Northern Greece. Environmental Monitoring and Assessment 123: 393-406. https://doi.org/10.1007/s10661-006-9204-y.

[12] Luzati S, Beqiraj A, Goga EB, Jaupaj O (2016) Iron and Manganese in Groundwater of Rrogozhina Aquifer, Western Albania. Journal of Environmental Science and Engineering B 5: 276-285. https://doi.org/10.17265/2162-5263/2016.06.002.

[13] Majumder RK, Halim MA, Saha BB, Ikawa R, Nakamura T, Kagabu M, Shimada J (2011) Groundwater flow system in Bengal Delta, Bangladesh revealed by environmental isotopes. Environmental Earth Sciences 64 (5): 1343-1352. https://doi.org/10.1007/s12665-011-0959-2.

[14] Majumder, RK., Shimada, J, and Taniguchi, M (2013) Groundwater flow systems in the Bengal Delta, Bangladesh, inferred from subsurface temperature readings. Songklanakarin Journal of Science and Technology 35 (1): 99-106.

[15] Moni SA, Satter GS, Reza, AHMS and Ahsan MA, (2019) Hydrogeochemistry and Arsenic Contamination of Shallow Aquifers in Bidyananda and Nazimkhan Unions, Rajarhat Upazila, Kurigram, Bangladesh. Journal Geological Society of India 94: 395-404. https://doi.org/10.1007/s12594-019$\underline{1327-1 .}$

[16] Ravenscroft P (2001) Distribution of Groundwater Arsenic in the Bangladesh related to Geology. In: P. Bhattacharya, G. Jacks \& A. A. Khan (Eds.), Groundwater arsenic contamination in the Bengal Delta Plain of Bangladesh. Proc KTH-Dhaka University Seminar, KTH Special Publication, pp. 4-56.

[17] Ravenscroft P, Burgess WG, Ahmed KM, Burren M, Perrin, J. (2005) Arsenic in groundwater of the Bengal Basin, Bangladesh: Distribution, field relations, and hydrogeological setting. Hydrogeology Journal 13: 727-751. https://doi.org/10.1007/s10040-003-0314-0.

[18] Reza AHMS, Jean J-S., Lee M-K, Yang H-J, Liu C-C (2010c) Arsenic enrichment and mobilization in the Holocene alluvial aquifers of the ChapaiNawabganj district, Bangladesh: a geochemical and statistical study. Appl. Geochem.25: 1280-1289. https://doi.org/10.1016/j.apgeochem.2010.06.006

[19] Saha S, Reza AHMS, Roy MK, (2020) Illite crystallinity index an indicator of physical weathering of the Sediments of the Tista River, Rangpur, Bangladesh: International Journal of Advanced Geosciences, 8(1): 27-32. https://doi.org/10.14419/ijag.v8i1.30551.

[20] Saha S, Reza AHMS, Roy MK, 2019 Hydrochemical evaluation of the groundwater quality of the Tista floodplain, Rangpur, Bangladesh: Applied Water Science, 9,198. https://doi.org/10.1007/s13201-019-1085-7.

[21] Saha, S, Roy MK, Reza AHMS (2018) Clay Mineralogical studies to access Provenance in Riverine Sequences, the Tista River, Rangpur, Bangladesh. International Conference on Geosciences and Environment (ICGE 2018), September 8-9, 2018, Department of Geology \& Mining, University of Rajshahi, Bangladesh. p. 48

[22] Shamsudduha M, Marzen LJ, Uddin A, Lee MK, Saunders JA (2009) Spatial relationship of arsenic distribution with regional topography and watertable fluctuations in the shallow aquifers in Bangladesh. Environmental Geology 57: 1521. https://doi.org/10.1007/s00254-008-1429-3.

[23] Shamsudduha M, Taylor RG, Ahmed KM, Zahid A (2011) The impact of intensive groundwater abstraction on recharge to a shallow regional aquifer system: evidence from Bangladesh. Hydrogeology Journal 19 (4): 901-916. https://doi.org/10.1007/s10040-011-0723-4.

[24] Smedley PL, Nicoli HB, MacDonald DMJ, Baros AJ, Tullio JO (2002) Hydrogeochemistry of arsenic and other inorganic constituents in groundwaters from La Pampa, Argentine. Applied Geochem. 17: 259-284. https://doi.org/10.1016/S0883-2927(01)00082-8.

[25] Stute M, Zheng Y, Schlosser P, Horneman A, Dhar RK, Hoque MA, Seddique AA, Shamsudduha M, Ahmed KM, van Geen A. 2007. Hydrological control of As concentrations in Bangladesh groundwater. Wat. Resour. Res., 43: W09417. https://doi.org/10.1029/2005WR004499.

[26] UN Report (2001) United Nations Synthesis Report on Arsenic in Drinking Water.

[27] Wasleker S (2013) Rivers of Peace Restructuring India-Bangladesh relationships. Strategic Foresight Group.

[28] Weinman B, Goodbred SL, Jr., Zheng Y, Aziz Z, Steckler M, van Geen A, Singhvi AK, Nagar YC. 2008. Contributions of floodplain stratigraphy and evolution to the spatial patterns of groundwater arsenic in Araihazar, Bangladesh. Geol. Soc. Am. Bull., 120: 1567-1580. https://doi.org/10.1130/B26209.1.

[29] WHO (2003) Iron in drinking-water, background document for development of who guidelines for drinking-water quality. WHO, Geneva.

[30] WHO (2008) Guidelines for drinking water quality. Recommendations, 3rd edn. WHO, Geneva.

[31] WHO (2011) Manganese in drinking-water, background document for development of who guidelines for drinking-water quality. WHO, Geneva.

[32] Zahid A, Hassan MQ, Balke KD, Flegr M, Clark DW (2008) Groundwater Chemistry and Occurrence of Arsenic in the Meghna floodplain aquifer, southeastern Bangladesh. Journal of Environmental Geology 54:1247-1260. https://doi.org/10.1007/s00254-007-0907-3. 